\title{
Pre and Post Process of Corporate Merger and Acquisition Technicalities
}

\author{
Rakesh Kumar Sharma, Anupam Sharma
}

\begin{abstract}
This research paper examines the overall merger and acquisition process and identifies the determinants of successful merger and acquisition for Indian companies. The acquisition process identified for this paper was classified into three stages, i.e., pre-acquisition management, post-acquisition integration, and post-acquisition performance evaluation. This process itself has a crucial role in deciding the success of the acquisition deal. Utilizing information from previous research, in the present study fifteen dimensions have been identified in three stages of merger and acquisition. These fifteen dimensions were employed as the building blocks of a successful acquisition transaction. Through synthesizing multiple dimensions in the overall acquisition process simultaneously, an attempt has been made to identify the content of specific factors that has affected a successful merger and acquisition deal.
\end{abstract}

Keywords: Merger and acquisition, pre-acquisition, determinants.

\section{INTRODUCTION}

The Mergers and acquisitions embody the ultimate in change for a business. No other incident is more difficult, challenging, or disordered as a merger and acquisition. It is crucial that everyone involved in the process has a clear understanding of how the process works. Hopefully this short course will provide you with a better appreciation of what is involved (Evans, 2000).

Regardless of the ultimate solution or desired outcome, begin with the same process. The core of the front-end steps in the M\&A and financing process is an analysis and understanding of the shareholders' and company's objectives, financial and competitive position, growth strategy and initiatives, and valuation.

Keep in mind that whether financing an acquisition, selling the entire company, raising a tranche of growth capital (in the form of debt or equity), or pursuing a recapitalization, what you are really selling is the future cash flow of the business. While past performance provides credibility to management's claims, future cash flow is the foundation for valuation and usually the primary reason for buying or investing in a

\section{Revised Manuscript Received on July 22, 2019.}

Dr. Rakesh Kumar Sharma (Assistant professor), School of humanities and social sciences, Thapar institute of engineering and technology, Patiala, Punjab.

Dr. Anupam Sharma (Assistant professor), School of humanities and social sciences, Thapar institute of engineering and technology, Patiala, Punjab company (Marks,2012).

Mergers and acquisitions are done by diverse companies for various motives. Some of them are to accelerate the growth, enhancing the company's financial performance, to improve the liquidity, to expand and diversify in different product lines also to reduce their business competitors. To accelerate the growth and Improve the financial performance are the important motives of M\&A. On overall M\&A acquisition is one strategy which ultimately want to enhance the value of firm or to maximise the value of shareholders' funds. Many research Many studies conducted outside India such as Lebudi (2010) in South Africa, Refnes (2012) in Europe, Park et al. (2001) in global country, Shin et al. (2005) in USA and Mulyana (2012) in Indonesia have discovered to accelerate growth and improve financial position are the key motives of merger and acquisition.

The present study employed the Delphi questionnaires as a research instrument to collect practitioners' and experts' opinions. For Round 1 of the Delphi, the questionnaire was comprised of four sets of questions constituting Sections I, II, III, and IV. In the questionnaire, this study employed Likert scales. As is a consideration with most of the popular scales, the Likert scale usually asks respondents to indicate whether they agree or disagree with provided statements (Neuman, 1994). In addition, this study employed four scales (or voting scales) rather than the more popular five or seven scales. For example, in Section II of the questionnaire, the study asked participants about the importance of each factor or variable within four scales, including unimportant (1), slightly important (2), important (3), and very important (4). This study investigated the acquisition policy.

This study attempted to determine the most important, influential factors that have significant, value-added impacts on corporate merger \& acquisitions in the Indian companies. Specifically, the study attempted to systematically discover evidence about the determinants of a successful pre-merger and acquisition management process, and the determinants of successful post-acquisition integration, as well as the identification of appropriate evaluation criteria for determining 
the post-acquisition erformance of an acquisition deal. In addition, this study tried to identify important merger and acquisition objectives of acquirer or merging company in India.

In order to achieve this present study's objectives, initially 60 operational indicators were identified from the general M\&A literature. By taking all these indicator structured questionnaire was designed. Then, assistance was sought in the form of a Delphi panel, from a group of M\&A practitioners and specialists in order to identify other important variables and to rate diverse critical success factors in the corporate merger and acquisitions process for the Indian companies

In order to organize and prioritize the collective judgment of a group of practitioners and specialists, the Delphi technique was employed as a primary methodology that involved iterative surveying of the same group. The procedure was to distribute the initial 60 operational indicators and ask the respondents to rate these variables according to their importance (or relevance). In each succeeding round, participants received feedback in the form of their own previous responses and any statistical or other data describing the entire group. It is believed that the Delphi technique leads to consensus on major points, as well as identifies minority opinions.

The group of respondents consisted of senior officers of Indian firms, industry consultants, and M\&A specialists in investment banks as a group of respondents. The panel examined the list of variables provided, and arrived at a final list of 60 critical success factors it judged relevant or important to the Indian firms in their investment decisions in corporate merger and acquisitions. Each item was rated in terms of its perceived influence on the entire acquisition process, based on a 4-point Likert-scale scale: a score of one (1) represents unimportant (or not relevant); two (2) denotes slightly important (relevant); three (3) represents important (relevant); and four (4) denotes very important (relevant). After the First Round, a group of 32 Delphi panelists was established and a total of 60 variables were presented the Delphi panel in the succeeding rounds. During the Second Round, 25 respondents reaffirmed or changed their initial votes. In order to expedite the process, participants in the Round 1 Delphi Questionnaire was furnished with a preliminary list of 60 such key factors in the corporate acquisition process. This inaugurating roster was presented to each panelist with the expressed mandate to appraise the level of the importance/relevance of each item
Table 1 Delphi panelist in 1 st Round, $2^{\text {nd }}$ round and $3^{\text {rd }}$ Round

\begin{tabular}{|c|c|c|c|c|}
\hline \multirow[t]{2}{*}{ Position } & \multicolumn{2}{|c|}{ Initial Sample } & \multicolumn{2}{|l|}{ Round-I } \\
\hline & $\begin{array}{l}\text { Numbe } \\
\text { r }\end{array}$ & $\%$ & $\begin{array}{l}\text { Numbe } \\
\mathbf{r}\end{array}$ & $\%$ \\
\hline $\begin{array}{l}\text { Vice } \\
\text { Chairman }\end{array}$ & 6 & 7.41 & 2 & $6.25 \%$ \\
\hline $\begin{array}{l}\text { President } \\
\& \mathrm{COO}\end{array}$ & 4 & 4.94 & 4 & $12.5 \%$ \\
\hline $\begin{array}{l}\text { Executive } \\
\text { Vice } \\
\text { President } \\
\& \text { CFO }\end{array}$ & 9 & 11.1 & 3 & $9.375 \%$ \\
\hline $\begin{array}{l}\text { Executive } \\
\text { Vice } \\
\text { President }\end{array}$ & 8 & 9.88 & 3 & $9.375 \%$ \\
\hline $\begin{array}{l}\text { Senior } \\
\text { Vice } \\
\text { President } \\
\& \text { CFO }\end{array}$ & 6 & 7.41 & 3 & $9.375 \%$ \\
\hline $\begin{array}{l}\text { Senior } \\
\text { Vice } \\
\text { President }\end{array}$ & 7 & 8.64 & 2 & $6.25 \%$ \\
\hline $\begin{array}{l}\text { Vice } \\
\text { President }\end{array}$ & 8 & 9.88 & 2 & $6.25 \%$ \\
\hline $\begin{array}{l}\text { Chief } \\
\text { Operating } \\
\text { Officer }\end{array}$ & 5 & 6.17 & 3 & $9.375 \%$ \\
\hline $\begin{array}{l}\text { Investment } \\
\text { Banker }\end{array}$ & 12 & 14.8 & 4 & $12.5 \%$ \\
\hline $\begin{array}{l}\text { M \& A } \\
\text { Consultant }\end{array}$ & 16 & 19.7 & 6 & $18.75 \%$ \\
\hline Total & 81 & 100 & 32 & $100 \%$ \\
\hline
\end{tabular}

\begin{tabular}{|l|l|l|l|l|}
\hline Position & \multicolumn{2}{|l|}{ Round-II } & \multicolumn{2}{l|}{ Round-III } \\
\hline & Number & $\%$ & Number & $\%$ \\
\hline $\begin{array}{l}\text { Vice } \\
\text { Chairman }\end{array}$ & 2 & 8 & 2 & 8 \\
\hline $\begin{array}{l}\text { President \& } \\
\text { COO }\end{array}$ & 3 & 12 & 3 & 12 \\
\hline
\end{tabular}




\begin{tabular}{|l|l|l|l|l|}
\hline $\begin{array}{l}\text { Executive } \\
\text { Vice President } \\
\text { \& CFO }\end{array}$ & 2 & 8 & 2 & 8 \\
\hline $\begin{array}{l}\text { Executive } \\
\text { Vice President }\end{array}$ & 2 & 8 & 2 & 8 \\
\hline $\begin{array}{l}\text { Senior Vice } \\
\text { President \& } \\
\text { CFO }\end{array}$ & 2 & 8 & 2 & 8 \\
\hline $\begin{array}{l}\text { Senior Vice } \\
\text { President }\end{array}$ & 2 & 8 & 2 & 8 \\
\hline Vice President & 2 & 8 & 2 & 8 \\
\hline $\begin{array}{l}\text { Chief } \\
\text { Operating } \\
\text { Officer }\end{array}$ & 2 & 8 & 2 & 8 \\
\hline $\begin{array}{l}\text { Investment } \\
\text { Banker }\end{array}$ & 4 & 16 & 4 & 16 \\
\hline $\begin{array}{l}\text { M \& A } \\
\text { Consultant }\end{array}$ & 4 & 16 & 4 & 25 \\
\hline Total & 25 & 100 & 160 \\
\hline
\end{tabular}

\section{THE MOST IMPORTANT/RELEVANT FACTORS IN THE MERGER AND ACQUISITION PROCESS}

The present study was conducted in three Delphi rounds and information related to pre and post M\&A period were retrieved from Delphi panelist. But in this research paper result of only third and final round have been analyzed. Further level of consensus of Delphi panelist about critical success factors in M\&A process have been determined by using inter quartile range and median.

\section{DISCUSSION \& CONCLUSION}

Present study is an empirical and analytical one that has been done to highlight the different issues of corporate merger acquisition process in the Indian companies and to study the post-merger and acquisition effects on the Indian companies. This study explored the underlying structure of the overall merger and acquisition process of Indian companies. Further, this study had identified important objectives of merger and acquisition of Indian companies, the important factor during pre and post M\&A stage and key success factors in the post-acquisition integration phase that will determine a successful acquisition deal in the Indian companies. This study has explored that to accelerate the growth of their firm is one of the most important objective of M\&A in Indian concern.

\section{Implication of the study}

Merger and acquisition can be one of the effective strategy, if this strategy is able to maximize the value of shareholders as well as value of firm. Every firm intends to undertake this kind of strategy to get the maximum gain of it. Present paper has explored the most important motives of merger and acquisition as well as various important determinants in the pre and post-merger stages. This study may helpful to the management or board of directors of companies for designing optimum strategy for merger and acquisition. As the most important factors identified in both the stages shall be more important for successfully implementation of merger and acquisition. This study will provide very useful information to management or board of directors of company regarding the important factors which are need to take care in successful implementation of merger and acquisition.

\section{REFERENCES}

1. Asquith, P. (1983). Merger bids, uncertainty, and stockholder returns Journal of Financial Economics, 11(2), 51-83.

2. Barney, J. (1991). Firm Resources and Sustained Competitive Advantage. Journal of Management, 17 (1), 99-120.

3. Bradley, B., Desai, A., \& Kim, E. H. (1983). Synergistic Gains From Corporate Acquisitions and Their Division between the Stockholders of Target and Acquiring Firms. Journal of Financial Economics, 21(3), 3-40.

4. Cannella, A. A., \& Hambrick, D. (1993). Effects of executive departures on the performance of cquired firms. Strategic Management Journal, 14, 137-152.

5. Cartwright, S., \& Cooper, C. L. (1993). The Role of Culture Compatibility in Successful rganizational Marriage. Academy of Management Executives, 7 (2), 57-70.

6. Chatterjee, S., Lubatkin, M., Schweiger, D., \& Weber, Y. (1992) Cultural Differences and Shareholder Value in Related Mergers: Linking Equity and Human Capital. Strategic Management Journal, 13, 319-334.

7. Datta, D. K., Pnches, G. E., \& Narayanan, V. K. (1992). Factors Influencing Wealth Creation from Mergers and Acquisitions: A Meta-Analysis. Strategic Management Journal, 13, 67-84. 